\title{
Human Metapneumovirus Infection in a Patient with Recurrent Wheezing: Case Report
}

\begin{abstract}
.
ABSTRACT

Lower respiratory tract infections are responsible for $28 \%$ of preventable and treatable childhood deaths under 2 years of age in the world. In recent years, due to advances on the factors of respiratory tract infections, new agents such as human metapneumovirus (hMPV), coronaviruses, human bocavirus, parvovirus type 4 and type 5 , and polyomavirus have been identified in addition to classical respiratory tract viruses. hMPV was first identified in the Netherlands in 2001. hMPV can lead to clinical manifestations ranging from mild upper respiratory tract infection, bronchiolitis and asthma attack, severe pneumonia to acute respiratory distress syndrome. In this article, a 23-month-old patient, who was followed-up with recurrent wheezing, respiratory distress, hypoxemia and in whom hMPV was identified as an etiologic agent, was presented for the purpose of drawing attention to the recent identification of the agent and its rare occurrence in the clinical practice.
\end{abstract}

Keywords: Bronchiolitis, human metapneumovirus, pneumonia, wheezing

\section{Tekrarlayan Hıșıltılı Hastada İnsan Metapnömovirüs Enfeksiyonu: Olgu Sunumu}

\author{
(1) Öner Özdemir1, (1) Onur Bircan² \\ 1Sakarya University Training and Research Hospital, Clinic of Allergy and Immunology, Adapazarı, Turkey \\ 2Sakarya University Faculty of Medicine, Department of Pediatrics, Adapazarı, Turkey
}

\section{öZ}

Dünyada 2 yaş altı önlenebilir ve tedavi edilebilir çocuk ölümlerinin \%28'inden alt solunum yolu enfeksiyonları sorumludur. Son yıllarda solunum yolu enfeksiyonlarının etmenlerine yönelik yapılan çalışmalardaki gelişmelere bağlı olarak klasik solunum yolu virüslerinin yanında insan metapnömovirüs (iMPV), koronavirüsler, insan bocavirüs, parvovirüs tip 4 ve tip 5 ve poliyomavirüs gibi yeni etmenler de tespit edilmiştir. iMPV ilk kez 2001 yılında Hollanda'da tespit edilmiștir. IMPV hafif üst solunum yolu enfeksiyonundan, bronşiolit ve astım atağına, ciddi pnömoniden akut respiratuvar distress sendromuna kadar varan klinik tablolara yol açabilir. Bu makalede tekrarlayan hıșıltı atağı, solunum sıkıntısı ve oksijen ihtiyacı nedeniyle takip edilen ve etken olarak iMPV saptanan 23 aylık hasta, etkenin son yıllarda yeni tanımlanması ve klinikte nadir görülüp tespit edilmesine dikkat çekmek amacıyla sunulmuştur.

Anahtar Kelimeler: Bronşiolit, insan metapnömovirüs, pnömoni, hışıltı

\section{Introduction}

Lower respiratory tract infections (LRTIS) are responsible for $28 \%$ of preventable and treatable child deaths under 2 years in the world (1). The most common causes of LTRIs below 2 years are viruses (2). Recent advances in respiratory tract infections have led to isolation of new agents such as human metapneumovirus (hMPV), coronaviruses, human bocavirus, parvovirus type 4 and type 5 , and polyomavirus in addition to classical respiratory tract viruses such as influenza, parainfluenza, adenovirus and respiratory syncytial virus (RSV) (3). HMPV was first isolated from the airways in the Netherlands in 2001 as a new paramyxovirus (4). HMPV causes LRTIs such as bronchiolitis and pneumonia besides upper respiratory tract infection.
In this article, a 23-month-old patient, who was followed-up with recurrent wheezing, respiratory distress, hypoxemia and in whom hMPV was identified as the etiologic agent, was presented for the purpose of drawing attention to the recent identification of the agent and its rare occurrence in the clinical practice.

\section{Case Report}

A 23-month-old boy was admitted to the hospital due to respiratory distress. He had a history of recurrent wheezing for a year and severe wheezing episodes, and he was hospitalized 3 times. He was on nebulized salbutamol, budesonide and montelukast therapy. The patient's respiratory distress had persisted for the last two weeks despite treatment. His vital signs were as follows: body temperature: $36.7^{\circ} \mathrm{C}$, 
respiratory rate: $50 /$ minute $(\mathrm{min})$, oxygen saturation $\left(\mathrm{sPO}_{2}\right)$ : $96 \%$, and pulse: 136/min. Physical examination revealed diffuse rhonchi in both lungs, and basal crepitant crackles. Laboratory results were as follows: white blood cells: $19.000 / \mathrm{mm}^{3}$ (range: $4.000-10.200 / \mathrm{mm}^{3}$ ), neutrophil count: $9.760 / \mathrm{mm}^{3}$, Hemoglobin: $13.1 \mathrm{~g} / \mathrm{dL}$ (range: $12-18 \mathrm{~g} / \mathrm{dL}$ ), platelet count: $405.000 / \mathrm{mm}^{3}$ (range: $142.000-424.000 / \mathrm{mm}^{3}$ ), C-reaktif protein (CRP): $54.4 \mathrm{mg} / \mathrm{dL}$ (range: $0-5 \mathrm{mg} / \mathrm{dL}$ ), sedimentation: 16/hr. (normal: $<20$ ). There was left perihilar fullness in the chest X-ray (Figure 1). The patient was started on salbutamol and ipratropium bromide treatment due to respiratory distress, and cefuroxime axetil treatment with a pre-diagnosis of bronchopneumonia with suspected bacterial agent. After the third day of treatment, systemic steroid ( $1 \mathrm{mg} / \mathrm{kg} /$ day) was initiated due to ongoing rhonchi. In order to investigate the etiology of recurrent wheezing episodes, immunoglobulin (Ig) G, A, M, E, IgG subgroups, specific antibody responses to past infections (anti-CMV IgG, anti-Rubella IgG and anti-HBs), CD3 in flow cytometric evaluation (T-cell), CD4, CD8, CD19 (B-cell), CD16 and CD56 (NK-cell) lymphocyte subgroups, isohemagglutinin (anti-A and anti-B) tests were performed and results were evaluated as normal. Purified protein derivative test (2 times) was negative. The sweat test was in normal range with 5.6 (range: $0-60) \mathrm{mmol} / \mathrm{L}$. On the $10^{\text {th }}$ day of the follow-up, his antibiotic

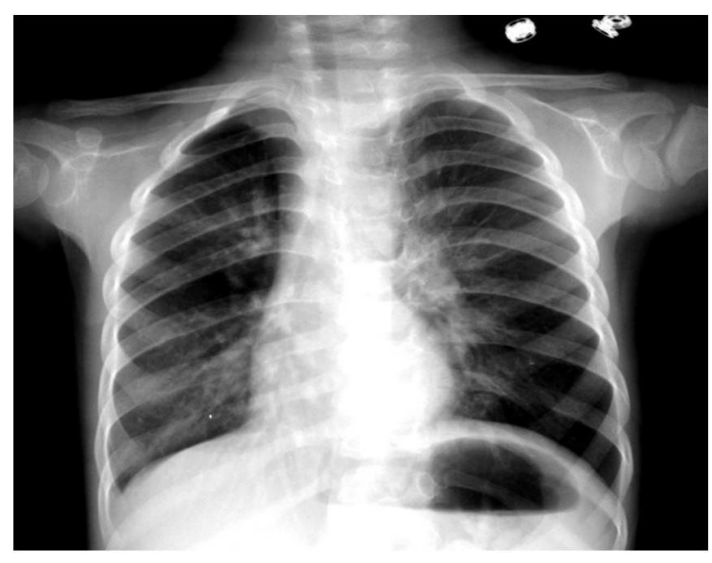

Figure 1. Left perihilar fullness, infiltrative appearance in the right lower and middle zones suggesting pneumonia and bilateral significant hyperaeration are noteworthy

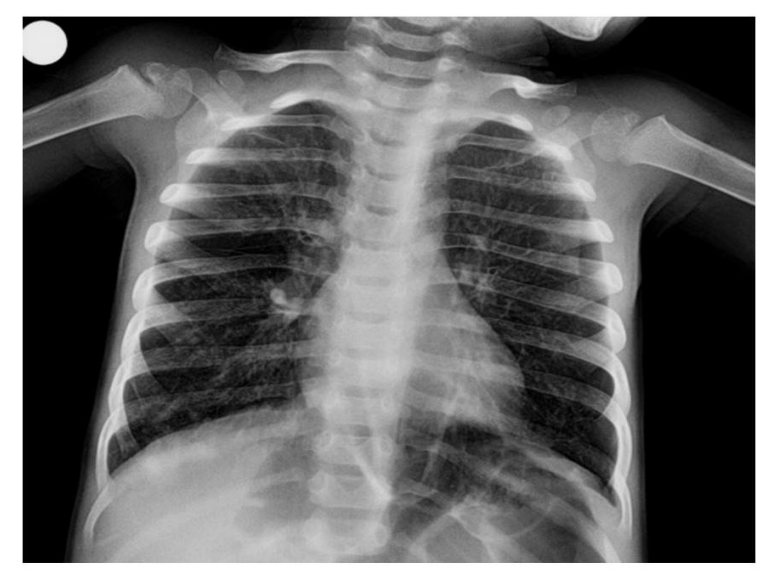

Figure 2. Prominent bronchovascular structures treatment was discontinued and the dose of nebulized salbutamol and ipratropium bromide was reduced. On the $11^{\text {th }}$ day of admission, his clinical condition improved and he complained of recurrent fever and vomiting while trying to cease the bronchodilator treatment. Urine and stool examination (adenovirus, rotavirus and microscopic examination) were evaluated as normal. At follow-up, complaints of $39{ }^{\circ} \mathrm{C}$ fever wheezing and respiratory distress, tachypnea and hypoxemia occurred, and the $\mathrm{SPO}_{2}$ of the patient decreased to $88 \%$. Supportive oxygen therapy was initiated. Blood cultures were obtained and a respiratory viral panel examination with polymerase chain reaction (PCR) was performed from the nasopharynx swab (Rotor-Gene Q platform, Qiagen, Germany). A total of 20 viruses were screened from 10 virus groups (influenza, rhinovirus, coronavirus, parainfluenza, hMPV A/B, bocavirus, RSV, adenovirus, enterovirus, and parechovirus). Despite negative blood cultures, hMPV was isolated from nasopharyngeal swab using PCR method. The patient was diagnosed as having hMPV-induced LRTI (bronchiolitis attack) and was discharged following observed improvement in hypoxemia and chest X-ray with conservative treatment (Figure 2). Oral patient consent was obtained from the family.

\section{Discussion}

HMPV is an RNA virus from the paramyxovirus family. People are the only source of infection for the virus. The disease is transmitted through the respiratory tract secretions of infected persons by droplets or direct contact (5). Personal hygiene and contact precautions are the main preventive methods for the prevention of virus transmission (6). Its frequency increases in winter and spring months. The most frequent months are March and April (7). The incidence is higher in boys than in girls. Unlike the RSV, it is more common in children between 6-21 months. Prodrome period lasts for 5-6 days and the clinical symptoms occur after (8). The typical course is the LRTI findings starting after a short asymptomatic period following the symptoms of the upper respiratory tract that lasts for two days. In many patients, wheezing lasts for several days, however, as in our patient, it may lead to LRTI (bronchiolitis) after an asymptomatic period, and may cause recurrent wheezing, and wheezing attacks and cough may continue for weeks in individuals with similar diseases $(9,10)$.

The most common clinical findings are cough, runny nose, fever restlessness, anorexia, wheezing and rarely nausea, vomiting and diarrhea. Auscultation findings include wheezing (52\%), and less frequently rhonchi (20\%) and crackles (8\%) (11). Radiographically, chest X-ray can show consolidation, perihilar infiltration, atelectasis and hyperinflation (12). Lymphopenia, transaminase elevation and CRP elevation can be detected in the laboratory tests (13). HMPV can lead to clinical manifestations ranging from mild upper respiratory tract infection, bronchiolitis and asthma attack, severe pneumonia to acute respiratory distress syndrome (9). The most common reason for hospitalization in hMPV infection is bronchiolitis and pneumonia (14).

In a study by Williams et al. (11), 59\% of the patients hospitalized for LRTI and diagnosed as having hMPV were evaluated as bronchiolitis, $8 \%$ as pneumonia, $18 \%$ as croup and $14 \%$ as asthma attack. Xepapadaki et al. (14) found hMPV in $16 \%$ of the patients hospitalized for bronchiolitis. In our patient, the clinical findings started as recurrent wheezing, followed 
by nasal discharge, subfebrile fever, nausea, vomiting and diarrhea, followed by a fever of $39^{\circ} \mathrm{C}$, respiratory distress and recurrent wheezing. There were no significant laboratory findings in our patient's blood tests except increased CRP (54.4 mg/dL). There was a perihilar infiltration in the chest X-ray.

Although the gold standard method is cell culture, the PCR test is widely used in diagnosis. It is not clinically useful since reproduction in viral cell culture can last 10-14 days (12). There was no growth in blood, urine and throat cultures of our patient. The hMPV was found to be positive by real-time PCR method in screening with viral respiratory panel.

There is no antiviral drug or vaccine approved for the treatment and prophylaxis of hMPV infection. Oxygen support therapy, and intravenous fluid therapy in patients with reduced oral intake, vomiting and diarrhea are supportive treatments. Bronchodilator and steroid therapy may be used in cases of asthma exacerbation. Antibiotic therapy may be necessary in cases of bacterial superinfection. There are studies suggesting that ribavirin and intravenous Ig treatment inhibit hMPV infection in vitro. There are case reports of ribavirin and intravenous Ig treatment used in the treatment of immunosuppressive patients $(12,15)$. The patient was given antibiotherapy due to the initial diagnosis of bacterial pneumonia, and conservative treatment was continued despite clinical deterioration after the diagnosis of hMPV-induced LRTI (bronchiolitis). The patient was discharged with healing after intravenous hydration, mask oxygen therapy and nebulized salbutamol.

Our patient was probably infected with hMPV infection while he was inpatient for correction of respiratory distress due to recurrent wheezing, but he was undergoing the prodrome period of the disease. In the first week of hospitalization for wheezing, the infection presented with upper respiratory tract symptoms in the asymptomatic period and became symptomatic with subsequent LRTI findings. In our patient, it is important to detect recurrent wheezing attack and to reveal the clinical picture that is caused by hMPV. Again, according to the literature, it is significant to show that the supportive treatment will be sufficient and the clinic is improved in the patient.

\section{Conclusion}

In cases of recurrent wheezing and asthma bronchitis exacerbations, hMPV infection should be considered and the clinical picture that it may cause should be known by other physicians, such as allergy and chest diseases specialists, dealing with respiratory diseases.

Informed Consent: Oral patient consent was obtained from the family.

Peer-review: Externally peer-reviewed.

Author Contributions: Concept - Ö.Ö.; Design - Ö.Ö.; Supervision - Ö.Ö.; Resources - O.B.; Materials - O.B.; Data Collection and/or Processing -
Ö.Ö., O.B.; Analysis and/ or Interpretation - Ö.Ö.; Literature Search - O.B.; Writing Manuscript - Ö.Ö., O.B.; Critical Review - Ö.Ö.

Conflict of Interest: There is no conflict of interest with any institution or company.

Financial Support: The authors declared that they did not receive financial support for this study.

\section{References}

1. WHO: Integrated management of childhood ilness. http://www. who.int/ child-adolescent-health 2003.

2. Özdoğan Ş. Çocuklarda toplum kökenli pnömoniye yaklaşım: Amerikan Çocuk Enfeksiyon Derneği Rehberi. S.E.E.A.H Tıp Bülteni 2015; 49: 163-73.

3. Akçalı S, Yılmaz N, Güler Ö, Şanildă̆ T, Anıl M. Alt solunum yolu enfeksiyonu olan çocuklarda solunum yolu viral etkenlerinin sıklı̆ı. Turk Pediatri Ars 2013; 48: 215-20.

4. van den Hoogen BG, de Jong JC, Groen J, Kuiken T, de Groot R, Fouchier RA, et al. A newly discovered Human Pneumovirus isolated from young children with respiratory tract disease. Nat Med 2001; 7: 719-24.

5. Peiris JS, Tang WH, Chan KH, Khong PL, Guan Y, Lau YL, et al. Children with respiratory disease associated with Metapneumovirus in Hong Kong. Emerg Infect Dis 2003; 9: 628-33.

6. TangYi- Wei, Crowe JE, Uyar Y. Respiratory Syncytical Virus and Human Metapneumovirus. In: Murray PR, Baron EJ, Pfaller MA, Jorgensen JH, Yolken RH, editors. 9.baskı. Ankara: Atlas Kitapçוlık; 2009. 1361-77.

7. Parlakay AÖ, Kara A. Yeni solunum yolu virüsleri. Çocuk Sağlı̆̆ı ve Hastalıkları Dergisi 2010; 53: 59-65.

8. Broor S, Bharaj P, Chahar HS. Human Metapneumovirus: a new respiratory pathogen. J Biosci 2008; 33: 483-93.

9. Boivin G, De Serres G, Côté S, Gilca R, Abed Y, Rochette L, et al. Human Metapneumovirus infections in hospitalized children. Emerg Infect Dis 2003; 9: $634-40$

10. Falsey AR, Erdman D, Anderson LJ, Walsh EE. Human Metapneumovirus infections in young and elderly adults. J Infect Dis 2003; 187: 785-90.

11. Williams JV, Harris PA, Tollefson SJ, Halburnt-Rush LL, Pingsterhaus JM, Edwards KM, et al. Human Metapneumovirus and lower respiratory tract disease in otherwise healty infants and children. N Engl J Med 2004; 350 443-50.

12. Schuster JE, Williams JV. Human Metapneumovirus. Pediatr Rev 2013; 34: 55865.

13. Alto WA. Human Metapneumovirus: a newly described respiratory tract pathogen. J Am Board Fam Pract 2004; 17: 466-9.

14. Xepapadaki P, Psarras S, Bossios A, Tsolia M, Gourgiotis D, Liapi-Adamidou G, et al. Human Metapneumovirus as a causative agent of acute bronchiolitis in infants. J Clin Virol 2004; 30: 267-70.

15. Wyde PR, Chetty SN, Jewell AM, Boivin G, Piedra PA. Comparison of the inhibition of Human Metapneumovirus and respiratory syncytial virus by ribavirin and immune serum globulin in vitro. Antiviral Res 2003; 60: 51-9. 